\title{
Tourism Entrepreneurs with Nature-Based Businesses in Sweden - The Role of the Lifestyle and the Place
}

\begin{abstract}
By Anna Sörensson ", Maria Bogren", Annika Cawthorn ${ }^{*}$
A growing amount of research focuses on lifestyle entrepreneurs in the tourism industry. Lifestyle entrepreneurs often go into business with the aim of making a hobby their income source or to create a certain quality of life in a specific place. Previous studies argue that lifestyle entrepreneurs are often motivated by non-economic goals. Nature-based businesses include traditional businesses such as those in the agriculture and forestry industries as well as new emerging businesses that are based on nature's resources such as tourism. In rural areas, these types of tourism businesses generate important income and are therefore of great importance from a business development perspective. The aim of this study is to explore how tourism entrepreneurs see their lifestyles and nature-based businesses in rural areas. The study was conducted using a qualitative approach. Seventeen different cases were studied between autumn 2015 and autumn 2016, all of which were nature-based businesses in the area of microtourism located in rural Sweden. Data were collected from semi-structured interviews, observations, and written material. The study's results show that there are several differences between tourism-lifestyle entrepreneurs in rural areas with nature-based businesses. We have identified four types of tourism-lifestyle entrepreneurs, each with different motives for running their businesses. The results also show that they focus differently on their naturebased businesses, depending on what kind of tourism entrepreneur they are. Many of the lifestyle entrepreneurs focus on developing several different types of income to reduce risk and obtain growth. Tourism-lifestyle entrepreneurs therefore seem to try different types of businesses and appear to be more open-minded and innovative where creating new products and services is concerned.
\end{abstract}

Keywords: Hipster Entrepreneur, Life Enjoyer, Lifestyle Entrepreneur, Motives, Nature Based, Tourism, Traditional Entrepreneur.

\section{Introduction}

Tourism entrepreneurship is an area of research that has not received the level of attention that it deserves (Ioannides and Petersen 2003). Since Schumpeter (1934), entrepreneurship and entrepreneurs have been seen as an important part of the development of sparsely populated regions. Nowadays, entrepreneurship is discussed in many different contexts and disciplines, including tourism. A

\footnotetext{
*Lecturer, Mid Sweden University, Sweden.

${ }^{\dagger}$ Senior Lecturer, Mid Sweden University, Sweden.

${ }^{\sharp} \mathrm{PhD}$ Student, Mid Sweden University, Sweden.
} 
growing number of research studies is focusing on lifestyle entrepreneurs in tourism (Ateljevic and Doorne 2000, Peters et al. 2009). Lifestyle entrepreneurs often start their businesses so they can make their hobby an income source or so they can create a certain quality of life in a specific place. Previous studies argue that lifestyle entrepreneurs are often motivated by non-economic goals (Shaw and Williams 2004). In this paper we will focus on tourism entrepreneurs whose main income is from nature-based businesses and who have extended their traditional farm operations to include tourism.

The Swedish government (2016) has named "Green industries" as a focus area for entrepreneurial development. The term "Green industries" ("Gröna näringar" in Swedish) means businesses within agriculture, forestry, landscape management, and other natural-resource-based commercial activities in rural areas. This concept does not exist in English, and in this study they will be referred to as "Nature-based businesses". Nature-based businesses include traditional businesses such as agriculture and forestry but also new emerging businesses that are based on nature's resources, such as tourism. In Sweden, nature-based businesses have great growth potential. Entrepreneurs in these businesses are considered to have a good forecast for growth and development since there is a high demand for products and services such as locally produced food, renewable energy, nature experiences, and rural tourism (Pettersson and Arora-Jonsson 2009). In rural areas, these types of businesses provide important income and are therefore of great importance where business development is concerned. Naturebased tourism businesses are often seen as providing a way of living for entrepreneurs who have a certain value and vision with their entrepreneurship (Pettersson and Arora-Jonsson 2009). The Swedish government sees this industry as being of particular interest for growing and creating new businesses. Since this industry is seen to be of great importance in Sweden, it is interesting to see how these entrepreneurs develop their business ideas to incorporate tourism. Over the years, nature-based businesses have struggled with, for example, the decline in milk prices and access to slaughterhouses. Political changes have led to less support for entrepreneurs with nature-based businesses such as agricultural businesses, which has led to an added focus on tourism. These changes have led to a steady decline in the number of agricultural businesses (Suess-Reyes and Fuetsch 2016). Among tourism entrepreneurs with nature-based businesses are entrepreneurs who have expanded existing businesses into the tourism sector. Previous research has shown that diversifying businesses, into tourism for example, is one way to create new business using existing resources such as buildings, labor, or equipment. Hansson et al. (2013) have shown the importance of, for instance, farm diversification into the tourism sector and also how this may change the identity of the farmers (Ilbery 1991, McNally 2001, Chaplin et al. 2004, Gorton et al. 2008, Barbieri and Mahoney 2009, Maye et al. 2009, Brandth and Haugen 2011, Grande 2011, Vik and McElwee 2011). For many nature-based businesses, the main motive for entrepreneurs running these businesses is the lifestyle they can offer as well as how they can be run as family businesses. Starting a business is often triggered by personal lifestyle goals in combination 
with the goal of living in a certain rural area, which often opposes pure economic driving forces (Ateljevic and Doorne 2000, Andersson Cederholm and Hultman 2010, Helgadóttir and Sigurdardóttir 2008, Marcketti et al. 2006, Andersson Cederholm 2015).

Previous research has also shown the importance of tradition and heritage among tourism entrepreneurs in nature-based businesses. These reasons are also important for understanding what motivates tourism entrepreneurs with naturebased businesses (Getz and Carlsen 2000, Hennon and Hildenbrand 2005, Hildenbrand and Hennon 2005, Andersson Cederholm 2015). It is important to realize that different types of entrepreneurs exist within this industry and that they have different goals with their businesses (Sörensson and Dalborg 2017). Entrepreneurs with nature-based businesses are often driven by the desire to choose a way of living and their own lifestyle. Nature-based businesses are also often family businesses due to family tradition (Anthias and Mehta 2003), and in Sweden there are many farms that have been passed from one generation to the next for long periods of time. Andersson Cederholm (2015) argues that family interests, personal lifestyle, leisure, and commercial interests are all important dimensions when discussing entrepreneurs with nature-based businesses. These types of entrepreneurs might not be driven by purely economic reasons. Andersson Cederholm (2015: 318) argues "in some types of family businesses, such as farming, the notion of heritage and tradition in connection to family life is important in order to understand what motivates the farm family." This complexity with many different reasons for being an entrepreneur with a nature-based business and hope of growth given by the government make it interesting to study entrepreneurs with nature-based businesses who have diversified into the tourism industry. The aim of this paper is to explore tourism entrepreneurs' points of view regarding their lifestyles and nature-based businesses in rural areas. This is examined in depth using the following research questions:

RQ1: What kind of motivations and values do tourism entrepreneurs in nature-based businesses have for their businesses in rural areas?

RQ2: What conditions do tourism entrepreneurs with nature-based businesses work under and what challenges do they face in developing and obtaining growth in rural areas?

In this paper, these entrepreneurs are referred to as tourism entrepreneurs with nature-based businesses. The paper is structured as follows. First a literature review is presented that addresses previous research in tourism in nature based business. In the next chapter the study's methodology is presented. Furthermore, findings and discussion are addressed in the next chapter. Finally, the conclusion of the study is presented. 


\section{Literature Review}

Some researchers use the term agri-culture tourism, which in this paper is interchangeable with tourism entrepreneurs with nature-based businesses. These businesses can include a variety of products and services, such as accommodation or on-farm attractions such as festivals and educational events. It can also include farmstays, bed-and-breakfast accommodation, pick-your-own produce, agricultural festivals, and farm tours for children, hayrides etc. (McGehee and Kim 2004).

The concept of entrepreneurship has changed over time and nowadays there are many different fields of research in this area such as economics, business administration, sociology, psychology, and tourism (Dawson et al. 2011). Different types of tourism entrepreneurs with nature-based businesses, and their motivation for entrepreneurship as well as the conditions they work under and the challenges that they face is the focus of this theoretical part.

Research on motivation for entrepreneurship plays an important role in starting new companies and is therefore highly significant when studying entrepreneurship (Carsrud and Brännback 2011, Segal et al. 2005, Shane et al. 2003). Bredvold and Skålén (2016), state that the traditional view of entrepreneurship would state that tourism entrepreneurs work towards the goal of maximizing economic profit. Traditional entrepreneurship research focuses on economics but also the attributes of entrepreneurs. The aim of most tourism entrepreneurs is to be their own boss, to be independent and to have an interesting job. Getz and Carlsen (2000) have identified two types of entrepreneurs in Australia: "family-first" and "business-first". Family-first entrepreneurs are motivated by emotional factors associated with their family and the desire to optimize their leisure time. Research has identified tourism entrepreneurs, however, as having goals other than economic goals, such as non-economic factors including lifestyle and family reasons. Dawson et al. (2011) discuss that research into entrepreneurship today includes a wider concept that includes cultural, economic, geographical, political and social factors. Getz et al. (2004) discuss "that the entrepreneurial process is not just an economic activity but is driven by the motivation of individuals as they seek to satisfy their own personal and social as well as economic goals".

Lifestyle tourism entrepreneurs are people who either balance economic and non-economic goals or are mainly motivated by lifestyle rather than economic goals (Morrison and Teixeira 2004, Dawson et al. 2011). Previous research has used the term "lifestyle" in different ways but the main idea is that non-economic factors are important for people who start their own business (Dawson et al. 2011). Other studies have shown that for many businesses, specifically in rural areas, the maintaining and protection of lifestyle is more important than profit maximization (Dawson et al. 2011). Niskanen (1998) has shown that entrepreneurs who have inherited farms that have been passed down the generations have the goal for the next generation to take over the farm. This has a larger emotional importance than other family businesses. 
Cardon et al. (2009) have discussed the importance of passion within entrepreneurship research. Already Schumpeter in 1934 stated it is "the joy of creating" that triggers an entrepreneur to start a business. Smilor (1997) argues that passion is seen as one of the most important areas within the entrepreneurial process. Research has shown that the passion from the tourism entrepreneur has a significant impact on creativity, endurance, and efficiency. Passion is also seen as being of great importance in developing a business and the ability to mobilize resources and establish relationships in starting up a business. Passion is therefore considered to have a positive impact in terms of managing the different roles that entrepreneurship requires (Baum and Locke 2004, Cardon et al. 2009, Sörensson and Dalborg 2017). One reason for this passion might be a certain geographic location. Entrepreneurs who are passionate about living in a certain place may have had the entrepreneurial process triggered by a desire to live there. Hallak et al. (2012) discuss place identity in relation to tourism entrepreneurs. In recent decades, research into place has included place attachment, sense of place, rootedness, place memory, community identity, community attachment, place dependence and place identity, just to name a few factors. In this paper, we focus on place identity as this includes a person's cognition, beliefs, perceptions, or thoughts that the self is invested in a particular spatial setting (Hallak et al. 2012). Ek and Hultman (2007) argue that place has different roles. Agnew (1987) states that there are three aspects that complement each other rather than compete with each other, namely location (1), sense of place (2), and locale (3). Location focuses on a place in relation to other places while sense of a place refers to subjective feelings that people have about a certain place. Locale refers to people's everyday relationships and how they act towards each other in a certain place or region (Ek and Hultman 2007). Place may play an important role for entrepreneurs and we think that current research into tourism entrepreneurs with nature-based businesses has failed to focus on this.

Kuhmonen et al. (2016) argue that three areas are of great importance when discussing rural areas among youth in Finland, namely livelihood (1), accommodation (e.g. location) (2), and lifestyle (3). The study shows that in rural areas, entrepreneurship is seen as an opportunity that comes with freedom of choice. It also shows that the lifestyle recipe could include nature-related and space-related activities. McElwee (2006) states that De Lauwere et al. (2002) have identified five groups of farmers; Economic entrepreneurs (1), socially responsible entrepreneurs (2), traditional growers (3), new growers (4), and doubting entrepreneurs (5). Economic entrepreneurs create a significant economic change while socially responsible entrepreneurs believe that economic success must be balanced with environmental and social factors. Traditional growers are focused on an activity that has a history of being successful while new growers try to diversify and try new but similar businesses such as tourism. Finally, doubting entrepreneurs are unwilling to make changes. It is therefore of great importance to understand the entrepreneur's identities, attitudes, and motivation (McFadden and Gorman 2016). Mottiar et al. (2018) examines the 
relevance of social entrepreneurs in rural destination development, which play a significant role in rural development. Social entrepreneurs within the tourism industry have a significant impact on tourism and development in rural areas. Social entrepreneurs, despite industry, is not focused on earning money but rather have other non-economic goals.

Hansson et al. (2013) discuss the fact that diversification is highly recommended by the European Union as a way to obtain growth and development in nature-based businesses. This could be done by helping farmers to find new or complementary commercial methods, such as tourism, using existing resources. Today, research often shows interest in farm diversification and entrepreneurship (Ilbery 1991, McNally 2001, Chaplin et al. 2004, Gorton et al. 2008, Barbieri and Mahoney 2009, Maye et al. 2009, Brandth and Haugen 2011, Grande 2011, Vik and McElwee 2011, Hansson et al. 2013). Many studies discuss how farmers often are "combiners", meaning that they have other work despite working on a farm as well. Farmers' motivation for diversifying their businesses is complex and includes many considerations other than economic reasons. The motivation underlying farmers' decision making is possibly context-dependent and therefore embedded in and dependent on their business' situation (Hansson et al. 2013). Many farms are run like family businesses and therefore the family's situation may play a more important role when decisions are made to expand the farm into the tourism industry.

\section{Methodology}

The starting point for this study came from a university course focusing on strategic issues for businesses. We realized that nature-based businesses in Sweden have not been studied from an entrepreneurial perspective. We prepared the study by conducting a literature review with a focus on lifestyle entrepreneurship. From this literature review, we decided that a quantitative study would not take into account the diversity of nature-based businesses while a qualitative approach would let us dig deeper into the business life of nature-based businesses. We conducted case studies on a total of 17 different businesses over the period of a year. We started in autumn 2015 and continued until autumn 2016. All 17 cases consisted of micro companies with naturebased businesses in the rural province of Jämtland in Sweden.

The province of Jämtland is situated in the middle of Sweden and borders Norway. It makes up 12 percent of Sweden's land area but is only home to 1.5 percent of Sweden's population. It is divided into eight municipalities. Together with the island province of Gotland, Jämtland has the highest rate of businesses in Sweden, currently 16 companies per 100 inhabitants. Jämtland also has the highest rate of entrepreneurship among women in Sweden with eight female entrepreneurs per 100 female residents in the age group 25-64. An impressive 48 percent of the population aged between 18 and 30 in the provinces of Jämtland and Västernorrland would prefer to be self-employed to being an employee, which 
is the highest figure in Sweden (SCB 2018). Jämtland is also one of Sweden's largest tourist destinations. Jämtland has 58,000 hectares of farmland, which comprises one percent of Sweden's total farmland. There are around 8,200 farms supporting 9,100 people; about seven percent of the population is permanently employed in this industry, which is above the national average. Agriculture in the province of Jämtland is dominated by milk and meat production, cattle are the most common livestock but sheep, pigs and reindeer are also farmed. Jämtland has 80 companies involved in reindeer husbandry and there are over 45,000 reindeer in the province. About 200-300 people are employed in this industry. After Gotland, Jämtland is the least industrialized region in Sweden with only 15 percent of the population involved. Industrialization is dominated by small businesses; only 50-60 of the province's industrial companies have more than 50 employees. More than 16 percent of Jämtland's industrial workers are active in forestry.

Figure 1. Map over Sweden and the Province of Jämtland

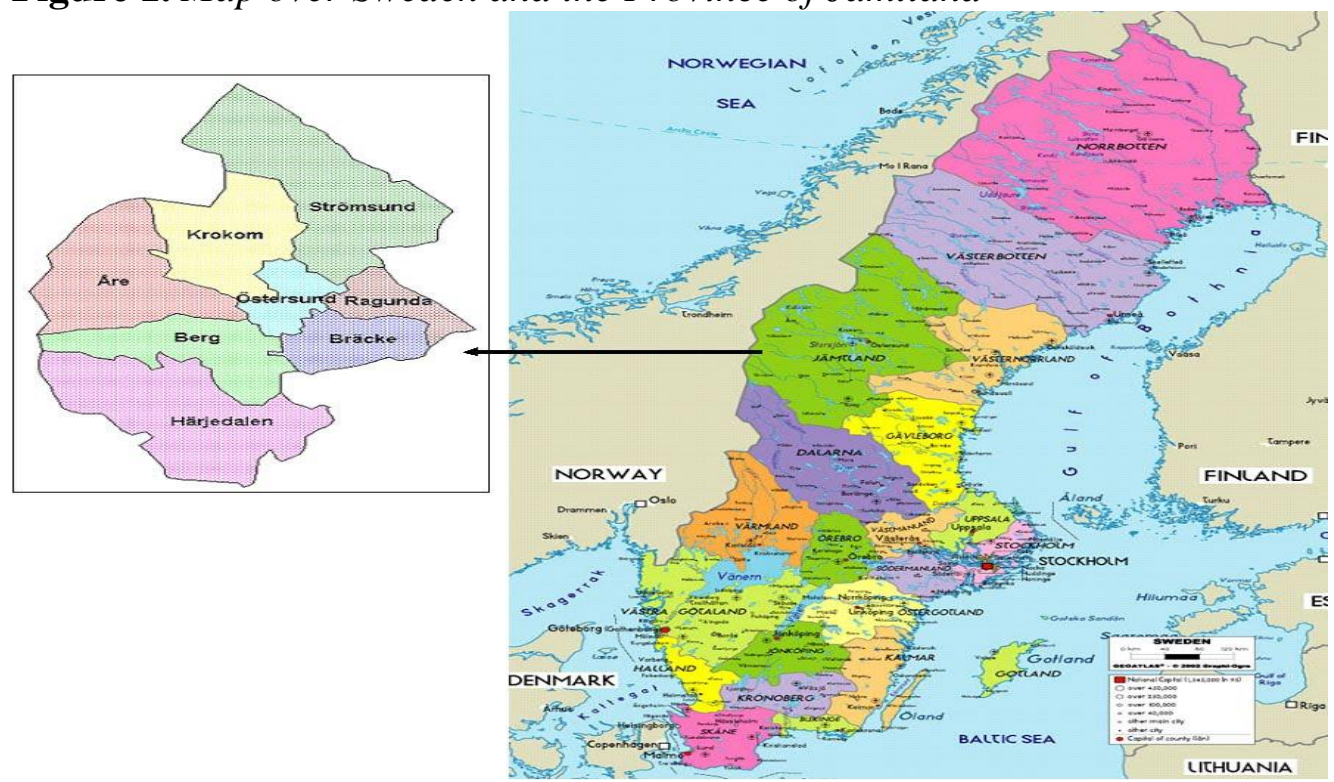

Source: Retrieved from http://reregions.blogspot.com/2009/10/jamtland-conty-council-sweden.html.

The study's data was collected using semi-structured interviews, observations, and written material. The interviews were conducted in various locations and notes were taken. The questions in the interviews focused on different areas of questioning such as: What is the company's current situation? What are its threats and possibilities? What are its challenges in the future? What kind of possibilities do tourism entrepreneurs see for development? How is it affected by being located in a rural area? The observations were made at the location of each business. Conditions were studied in terms of buildings and the surrounding area, but also how the distance to the nearest major location could be perceived and if there were any available transportation options. Documents that were studied included written sales material and the business' website and Facebook pages. Each case was then treated as a separate unit and was not compared to the other cases 
until all data collection was finished. The 17 cases were then analyzed and categorized with an interpretative approach based on the study's themes.

\section{Findings and Discussion}

The tourism entrepreneurs' views on their lifestyles and nature-based businesses show that they base their businesses on their interests. All of these companies base their businesses on what nature can offer. About half of the tourism entrepreneurs own land and forest. They also have other assets in the form of buildings and animals. A common trait in all the tourism entrepreneurs is that they have a strong interest in nature-based businesses. They are very interested in nature and have built their income on this interest. The result also shows that the tourism entrepreneurs' background and interest play an important role in what type of business they have. They also seem to have a large social network. A strong interest is the passion or joy of creating. Their lifestyle includes spending a lot of time in nature and they have made this part of their business life.

This burning interest among the tourism entrepreneurs gave them great experience and the knowledge they needed to move on in business and develop their ideas. A common feature is that the entrepreneurs within nature-based businesses conduct their business in a genuine way and with authenticity. Many of the tourism entrepreneurs focus their production on "locally-grown products" or locally produced goods. Most of them prefer to sell their products at local markets and many have started different tourism businesses. It is important to minimize transportation for their customers. There is a great demand for ecological products and there is also an active debate that benefits businesses that focus on ecological products, especially concerning food in Sweden. Sustainable tourism is also a much-discussed issue today and ecological alternatives are something that people choose more and more. Many of the farmers produce high-quality meat products that are also more effective since they can sell them for a higher price. Another common trait is that many of the entrepreneurs own large amounts of land, both forested and farmland. The value of forestry is important and can be seen as an "insurance" in times of instability (the price on milk and meat differ depending on international markets). Some of the tourism entrepreneurs see this as a possibility to invest in other business ideas. They also spread the risk by conducting business in different areas such as forestry, dairy production, and tourism, all on the same farm.

The results of this study show that there are several differences between lifestyle entrepreneurs in rural areas with nature-based businesses. The study's 17 different cases have shown a pattern that we used to construct the following model. Four types of entrepreneurs were identified, all with different motives for running their businesses. The motives differ according to economic goals and what kind of life they are looking for. The categories are labelled traditional entrepreneur (1), enjoyer of life (2), lifestyle entrepreneur (3), and hipster 
entrepreneur (4). The traditional entrepreneur is mainly looking for economic growth while lifestyle and place are not of great importance. The enjoyer of life is not aiming for economic profit nor a specific lifestyle or location, but is rather more of an artistic sort. The lifestyle entrepreneur is primarily not looking for economic growth but the location and the lifestyle are highly important to these entrepreneurs. The final category identified was "hipster entrepreneurs" who are aiming for a combination of lifestyle and living in a specific location Hipster entrepreneurs are more often found within the tourism industry.

Figure 2. Entrepreneurs with Nature-Based Businesses

Focus on economic Focus on way of life

Focus on product/ service

Focus on the place

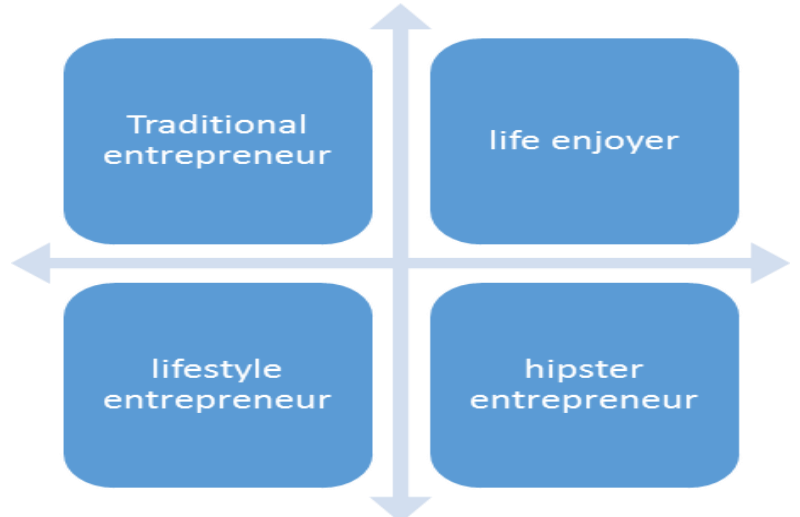

Source: Author.

The study shows that the place are relevant to discuss in relation to the studied cases. Ek and Hultman (2007) discuss place from three different perspectives: location, sense of place, and locale. In this study we could see that traditional entrepreneurs mainly see location as the important factor. Some of the entrepreneurs have inherited their farm, making the location very important due to family history. There are other entrepreneurs who are more focused on the sense of the place. They like a place because of the feeling that a certain place has. They want to live there and enjoy that feeling in their everyday life and have therefore tried to find a way to make a living there. These are the lifestyle entrepreneurs that are presented in Figure 1. The third perspective that Ek and Hultman (2007) address is the locale. Locale is the focus of both the enjoyer of life as well as the hipster entrepreneur. Both of these categories focus on relationships with others. The other people living in a certain place become important and may be a reason for choosing to live there.

The tourism entrepreneurs seem to have different motives and values as shown in Figure 1. All the entrepreneurs see nature and the environment as central aspects in their businesses. Some of them see the possibility to live and work on their own farm as a great opportunity and they value this highly. They use the resources that the farm and land can offer to make it possible to remain there. Many of them also want to share these values with other people through 
tourism, for example, many children today are not aware that milk comes from cows so farm tours are organized. It is also important to spread information about how animals are kept from an ethical point of view. People are becoming more aware of the importance of these issues and are interested in buying farms products and tourism products that are responsibly produced. The knowledge level among the tourism entrepreneurs becomes an asset since they have the expertise to make it into a business. Another result from this study is that the entrepreneurs are very genuine. The combination of tourism entrepreneurs who have a strong knowledge of nature and who operate with respect to nature becomes authentic. All of these companies have a strong place attachment but in different ways. They are also more family-first oriented than business-first oriented (Getz and Carlsen 2000).

The results show that tourism entrepreneurs have both differences as well as challenges in common within their business life. Most of the tourism entrepreneurs are highly dependent on themselves and their family members. This makes their businesses very vulnerable in cases of sickness, accidents or separation. About half of them hire seasonal employees. They do not have the financial possibility to hire people on a permanent basis, only during peak seasons. Many of the tourism entrepreneurs would like to hire more staff on a regular basis so they could find the time for business development.

These businesses are dependent on EU funding and some of them also apply for funding to develop their businesses. When farmers need to develop their buildings, the costs are high. There are often too few employees to fully maintain the care of the farm, including cleaning, administration, and maintenance of buildings. Many of the tourism entrepreneurs do not have enough time to work with marketing, which is of importance since customers need to find them in a highly competitive market. Some of the tourism entrepreneurs do not even have the skills and/or the interest to work with their website and Facebook page, for example. The rapid technological advances seen today are a challenge for many small business owners.

The practical implications from this study is that tourism entrepreneurs in nature-based businesses are driven by different goals. This should be taken into account by the politicians to be aware that all entrepreneurs are not driven by economic reasons. It is therefore of importance to create places where entrepreneurs want to live and run their tourism business.

\section{Conclusion}

This study should be seen as a first attempt to find out more about tourism entrepreneurs with nature-based businesses. The different cases have shown differences between the tourism entrepreneurs as well as within the industry itself. In conclusion, we identified four different categories of tourism entrepreneurs. Place plays an important role for lifestyle entrepreneurs and hipster entrepreneurs with nature-based businesses. One of the main motivations for these tourism 
entrepreneurs is to live in a certain location. The results also show that depending on what kind of entrepreneur they are, they focus differently on their naturebased businesses. Many of the lifestyle entrepreneurs are focused on finding several different types of income to spread the risk and also obtain growth. The study also shows that traditional entrepreneurs with nature-based businesses prefer to focus on the main income and not so much on tourism. The lifestyle entrepreneurs therefore seem more willing to try different types of businesses and appear more open minded to create and innovate new products and services.

It would be interesting to continue this study by investigate other industries to see if the four categories also exist there. We would also like to do a comparative study with other countries to see if the categories also exist despite other national cultures.

\section{References}

Agnew, J. (1987). Place and Politics. The Geographical Mediation of State and Society. UK: Routledge.

Andersson Cederholm E, Hultman J (2010) The value of intimacy-negotiating commercial relationships in lifestyle entrepreneurship. Scandinavian Journal of Hospitality and Tourism 10(1): 16-32.

Andersson Cederholm E (2015) Lifestyle enterprising: the 'ambiguity work'of Swedish horse-farmers. Community, Work \& Family 18(3): 317-333.

Anthias F, Mehta N (2003) The intersection between gender, the family and selfemployment: the family as a resource. International Review of Sociology/Revue Internationale De Sociologie 13(1): 105-116.

Ateljevic I, Doorne S (2000) 'Staying within the fence': Lifestyle entrepreneurship in tourism. Journal of Sustainable Tourism 8(5): 378-392.

Barbieri C, Mahoney E (2009) Why is diversification an attractive farm adjustment strategy? Insights from Texas farmers and ranchers. Journal of Rural Studies 25(1): $58-66$.

Baum JR, Locke EA (2004) The relationship of entrepreneurial traits, skill, and motivation to subsequent venture growth. Journal of Applied Psychology 89(4): 587-598.

Brandth B, Haugen MS (2011) Farm diversification into tourism-implications for social identity?. Journal of Rural Studies 27(1): 35-44.

Bredvold R, Skålén P (2016) Lifestyle entrepreneurs and their identity construction: A study of the tourism industry. Tourism Management 56: 96-105.

Cardon MS, Wincent J, Singh J, Drnovsek M (2009) The nature and experience of entrepreneurial passion. Academy of Management Review 34(3): 511-532.

Carsrud A, Brännback M (2011) Entrepreneurial motivations: what do we still need to know? Journal of Small Business Management 49(1): 9-26.

Chaplin H, Davidova S, Gorton M (2004) Agricultural adjustment and the diversification of farm households and corporate farms in Central Europe. Journal of Rural Studies 20(1): 61-77.

Dawson D, Fountain J, Cohen DA (2011) Seasonality and the lifestyle "conundrum": An analysis of lifestyle entrepreneurship in wine tourism regions. Asia Pacific Journal of Tourism Research 16(5): 551-572.

Ek R, Hultman J (2007) Plats som Produkt. [Place as Product]. Lund: Studentlitteratur. 
Getz D, Carlsen J (2000) Characteristics and goals of family and owner-operated businesses in the rural tourism and hospitality sectors. Tourism Management, 21(6): 547-560.

Getz D, Carlsen J, Morrison A (2004) The Family Business in Tourism and Hospitality. UK: CABI.

Gorton M, Douarin E, Davidova S, Latruffe L (2008) Attitudes to agricultural policy and farming futures in the context of the 2003 CAP reform: A comparison of farmers in selected established and new Member States. Journal of Rural Studies, 24(3): 322336.

Grande J (2011) New venture creation in the farm sector-Critical resources and capabilities. Journal of Rural Studies, 27(2): 220-233.

Hallak R, Brown, G, Lindsay NJ (2012) The place identity-performance relationship among tourism entrepreneurs: a structural equation modelling analysis. Tourism Management 33(1): 143-154.

Hansson H, Ferguson R, Olofsson C, Rantamäki-Lahtinen L (2013) Farmers' motives for diversifying their farm business-the influence of family. Journal of Rural Studies 32: 240-250.

Helgadottir G, Sigurðardóttir I (2008) Horse-based tourism: Community, quality and disinterest in economic value. Scandinavian Journal of Hospitality and Tourism, 8(2): 105-121.

Hennon CB, Hildenbrand B (2005) Modernising to remain traditional: farm families maintaining a valued lifestyle. Journal of Comparative Family Studies 36(3): 505520 .

Hildenbrand B, Hennon CB (2005) Above all, farming means family farming: context for introducing the articles in this special issue. Journal of Comparative Family Studies 36(3): 357-366.

Ilbery BW (1991) Farm diversification as an adjustment strategy on the urban fringe of the West Midlands. Journal of Rural studies 7(3): 207-218.

Ioannides D, Petersen T (2003) Tourism 'non-entrepreneurship'in peripheral destinations: a case study of small and medium tourism enterprises on Bornholm, Denmark. Tourism Geographies 5(4): 408-435.

Kuhmonen T, Kuhmonen I, Luoto L (2016) How do rural areas profile in the futures dreams by the Finnish youth?. Journal of Rural Studies 44: 89-100.

De Lauwere C, Verhaar K, Drost H (2002) Het Mysterie van het Ondernemerschap, boeren en tuinders op zoek naar nieuwe wegen in een dynamische maatschappij. [The Mystery of Entrepreneurship; Farmers looking for new pathways in a dynamic society, In Dutch with English summary], Wageningen University and Research Centre.

Marcketti SB, Niehm LS, Fuloria R (2006) An Exploratory Study of Lifestyle Entrepreneurship and Its Relationship to Life Quality. Family and Consumer Sciences Research Journal 34(3): 241-259.

Maye D, Ilbery B, Watts D (2009) Farm diversification, tenancy and CAP reform: Results from a survey of tenant farmers in England. Journal of Rural Studies 25(3): 333-342.

McElwee G (2006) The enterprising farmer: a review of entrepreneurship in agriculture. Royal Agricultural Society of England Journal 167(January): 66-75.

McFadden T, Gorman M (2016) Exploring the concept of farm household innovation capacity in relation to farm diversification in policy context. Journal of Rural Studies 46: 60-70. 
McGehee NG,Kim K (2004) Motivation for agri-tourism entrepreneurship. Journal of Travel Research 43(2): 161-170.

McNally S (2001) Farm diversification in England and Wales - what can we learn from the farm business survey?. Journal of Rural Studies 17(2): 247-257.

Morrison A, Teixeira R (2004) Small business performance: a tourism sector focus. Journal of Small Business and Enterprise Development 11(2): 166-173.

Mottiar Z, Boluk K, Kline C (2018) The roles of social entrepreneurs in rural destination development. Annals of Tourism Research 68: 77-88.

Niskanen K (1998) Föreställningar om Kön: Ett Genusperspektiv på Jordbrukets Modernisering [Expectations on Gender: A Gender Perspective on Agricultural Modernization]. Stockholm: Acta Universitatis Stockholmiensis.

Peters M, Frehse J, Buhalis D (2009) The importance of lifestyle entrepreneurship: A conceptual study of the tourism industry. Pasos 7(2): 393-405.

Pettersson K, Arora-Jonsson S (2009) Den Osynliga Entreprenören: Genus och Företagande i De Gröna Näringarna. [The Invisible Entrepreneur: Gender and Business in the Nature Based Businesses]. Stockholm: LRF's Jämställdhetsakademi.

Schumpeter JA (1934) The Theory of Economic Development. Oxford: Oxford University Press.

Segal G, Borgia D, Schoenfeld J (2005) The motivation to become an entrepreneur. International Journal of Entrepreneurial Behavior \& Research 11(1): 42-57.

Shane S, Locke EA, Collins CJ (2003) Entrepreneurial motivation. Human Resource Management Review 13(2): 257-279.

Shaw G, Williams A (2004) From lifestyle consumption to lifestyle production: changing patterns of tourism entrepreneurship. In Small Firms in Tourism (chapter seven) 99113. Available at: https://doi.org/10.1016/B978-0-08-044132-0.50010-1.

Smilor RW (1997) Entrepreneurship: Reflections on a subversive activity. Journal of Business Venturing 12(5): 341-346.

Suess-Reyes J, Fuetsch E (2016) The future of family farming: A literature review on innovative, sustainable and succession-oriented strategies. Journal of Rural Studies 47(Part A): 117-140.

Sörensson A, Dalborg C (2017) Female entrepreneurs in nature-based businesses: working conditions, well-being, and everyday life situation. Society, Health \& Vulnerability 8:1. Available at: https://doi.org/10.1080/20021518.2017.1306905.

Swedish Government (2016). Retrieved from https://bit.ly/2r8FlQN. [Accessed 15 June 2018].

SCB (2018) Statistics in Sweden. Available at: https://www.scb.se/vara-tjanster/ foretagsregistret/.

Vik J, McElwee G (2011) Diversification and the entrepreneurial motivations of farmers in Norway. Journal of Small Business Management 49(3): 390-410. 
